Hills of Yorkshire. The so-called 'pans' differ markedly, depending on the looseness of texture of the underlying glacial deposits. The essential difference between the upland heaths of Britain and the continental heaths of Denmark, Germany and the Netherlands is clearly explained in Chapter 2. While such differences may justify the adoption of a completely independent attitude in Britain they do not excuse the neglect of the important work done in France by Duchaufour on heath soils or by Scandinavian, other than Danish, workers. Nor is the ignoring of the heath afforestation carried out in Great Britain long before the Forestry Commission was constituted excusable. Whether Continental heaths have " $\mathrm{a}$ longer history of systematic afforest ation than our own" depends on what is meant by 'systematic'. The skilled tree-planters of Britain, in the eighteenth and nineteenth centuries, with $a$ life-time of experience behind them, came to very definite conclusions about suitability of species, the value of ploughing and other techniques, and in forestry a life-time of experience in one locality may compensate for lack of intensive experiment at heavy cost, and the use of statistical methods to support the very obvious results which the intelligent observer sees and records in his memory, if not in his note-book. This is possibly rank heresy, but when one is confronted with the meagre conclusions from thirty-six years of intensive experiments, involving a multitude of measurements and calculations, one may be permitted to wonder if the capacity of the human brain is not nowadays underestimated.
Mr. Zehetmayr deserves great credit for the immense pains which he has taken to range over space, at least, and make himself conversant with heath-land planting. $\mathrm{He}$ has dealt with the enormous accumulation of experimental data in a masterly manner and makes good use of figures and illustrations. As a result of his breadth of vision, his conclusions are sound and are devoid of the exaggeration and puerile propaganda which sometimes detract from the value of forestry technical publications. He also places the important work so far achieved in its correct perspective historically, although perhaps his glance has been directed too far ahead and not enough backwards. Much more intensive soil research, as opposed to more-or-less empirical experimentation, is now required if further real progress is to be made. Meanwhile, adopting the same cautious attitude as the author, foresters and tree-planters would do well to be conservative, rather than rash, in their attitude, and to esohew the high-living tree species in favour of the abstemious. They should read and apply the lessons so far learned with discrimination, paying special heed to variation in locality conditions. In particular, deep ploughing on a large scale should not be used indiscriminately; it is often not only unnecessary but also harmful, especially in its effect on the drainage of catchment areas. The dweller in the lowlands is often unaware of what is happening in the uplands in these days. The excellenee of $\mathbf{M r}$. Zehetmayr's interpretation will give great satisfaction to all who have participated in this project.

M. L. ANDERSON

\title{
REORGANIZATION OF BRITISH NATIONALIZED TRANSPORT UNDERTAKINGS
}

$\mathrm{N}$ EITHER in the White Paper on the Reorganization of the Nationalized Transport Undertaking** nor in the debate on January 30, in which the Minister of Transport, Mr. E. Marples, asked the House of Commons to take note of the proposals for reorganization, was any reference made to the importance of research or of a sufficiency of scientific and technical man-power in Britain. Furthermore, the organization chart appended to the White Paper gives no indication as to how the organization for research is affected. The White Paper puts as the Government's aim undertakings soundly based on organization and finance, providing efficient services and giving a good livelihood and worth-while jobs to those who work in them. It directs attention to the fact that the railways are a vital basic industry, employing 500,000 people and representing an investment of nearly $£ 1,600$ million, still growing by more than $£ 100$ million each year. A railway system of the right size is regarded as an essential element in the British transport network, and will remain so for as long as can be foreseen, but the White Paper does not discuss the vital question: What is the right size? The related question of congestion on the roads is ignored, and while the idea of the railways as a social service is rejected, the question of uneconomic services such as branch lines is reserved for further consider.

* Ministry of Transport. Reorganization of the Nationalized Trans. port Undertakings. Pp. 14. (Cmnd. 1248.) (London : H.M. Stationery Office, 1960.) 18. net. ation; it is merely stated that for the time being railway losses on any such services will be covered by the contributions proposed from public funds.

This point was stressed during the debate by Sir Toby Low, chairman of the Select Committee on Nationalized Industries, who, while agreoing that, in the main, the Government's proposals were in line with the recommendations of the Select Committee, was doubtful whether full control over the finances of the railway system could be achieved until the problem of dealing with uneconomical services had been decided. Sir Toby insisted that we could find out why losses are incurred, and he urged in con. clusion that the real problem was not money but morale. Success can only be achieved by the vigorous use of every instrument of management and of science. Apart, however, from the Minister's announcement that the Government had decided that the main-line electrification scheme from Euston to Crewe, Manchester and Liverpool should go ahead as quickly as was consistent with the best use of the available resources, nothing in the debate clarified the uncertainty about the progress of modernization or the future of the uneconomical services. The Joint Parliamentary Secretary to the Ministry of Transport, Mr. John Hay, did not accept Sir Toby Low's challenge, and only stated that in 1960 the Treasury provided $£ 160$ million and in $1961 £ 140$ million for investment in the railway industry, as a result of which more than seventy major projects had already 
been approved. Earlier, Mr. Marples had said that he would have to keep the electrification scheme (which is to cost $£ 175$ million) under close review to see how the estimates of cost and the rate of working compared, but that this did not necessarily mean that no other major main-line electrification scheme would be approved.

The White Paper states that the main conclusions reached by the Government are that the activities of the British Transport Commission, as at present constituted, are so large and diverse that it is virtually impossible to run them effectively as a single undertaking. There has been confusion in judging between what is economically right and what is socially desirable, and the commercial capability of the railways is circumscribed by outmoded statutory obligations and restrictions on their trading operations. Mounting deficits (now totalling $£ 500$ million), the size of capital debt in relation to the earning capacity of the assets and the increasing burden of interest (a]ready some $£ 75$ million alone) as modernization proceeds, present a situation detrimental to the morale of management and workers, to financial control and to hope of recovery. Accordingly, the Government has decided to replace the British Transport Commission and the existing organization by a new structure designed to overcome the main defects and disadvantages of the present organization, to reconstruct the finances of the Commission, and of the railways in particular, and to give the various undertakings the maximum practicable freedom of operation in their commercial affairs.

In the new structure, each of the main activities of the present Transport Commission-railways,
London Transport, docks, inland waterways-will be managed by a separate Board holding its own assets and responsible for its own capital debt. The British Railway Board will be responsible for running the railways as an effective national system, but will perform only those central functions which are essential to the running of the railways as a single entity, including policies for safety, training and research, and the determination of the future size and shape of the railway system; all other functions will be the responsibility of the Regional Railway Boards. Co-ordination of policy between the new Boards for railways, London Transport, docks and inland waterways will be the responsibility of the Minister of Transport, assisted by a new Nationalized Transport Advisory Council. His special duties in respect of safety, training and research will continue. As regards finance, the Government proposes to write off $£ 400$ million of the $£ 2,000$ million capital liabilities of the British Transport Commission, and when $£ 400$ million of the remainder has been transforred to the appropriate new Boards, to place in suspense $£ 800$ million of the $£ 1,200$ million still remaining against the railways so that it carries neither fixed interest nor fixed repayment obligations. The amount and treatment of this suspense account will be subject to review from time to time in the light of developments. It is expected that the railways will eliminate their present operating loss of $£ 60$ million a year. The importance of efficient operation and the most economic use of man-power is also emphasized, and the railways are to be freed from statutory control over their charges except for fares in the London Passenger Transport Area.

\section{THE AGADIR EARTHQUAKE}

\begin{abstract}
FOLLOWING a detailed local study of the Agadir earthquake of February 29, 1960, P. Erimesco has published the conclusions in the Bulletin de L'Institut des Pêches Maritimes du Maroc (No. 5; September 1960). The author states that earth tremors in Morocco are not infrequent, although they very seldom attain an intensity of more than 5 on the Mercalli scale. In the list given in the text for the period from May 31, 1934, to October 28, 1951, eighteen earthquakes have intensity 4 or greater. Two of these were of intensity 7 , and four had maximum intensity 6. The town of Agadir is situated at the intersection of two lines of marked seismicity. One line follows the region between the High Atlas Mountains and the Anti Atlas. The other crosses the High Atlas Range and continues to the coast of the Mediterranean.

During the night of February 29, 1960, after two slight tremors, an earthquake of unusually high intensity for the region $(\mathrm{IX}-\mathrm{X})$ devastated the town of Agadir (initial time 23h. 40m. 12s. G.M.T.). According to the map produced by the author, showing isoseismal lines for the shock, the small region of greatest intensity inside isoseismal $\mathbf{X}$ lies just on shore. The local estimate of depth of focus lies between 3 and $7 \mathrm{~km}$., and of the magnitude of the shock $5 \cdot 75$ to 6 . According to Vít Kárník, of Czechoslovakia, the average formula connecting magnitude $(M)$, intensity $\left(I_{0}\right)$ at epicentre, and depth of focus (h) for European shocks is :
\end{abstract}

$$
M=0.67 I_{0}+1 \cdot 7 \log h-1 \cdot 4
$$

For $I_{0}=10$ and $h=5 \mathrm{~km}$. this gives $M=6 \cdot 48$, which is somewhat higher than the local estimate.

Whole areas of the town, situated near the port and along the shore, suffered very heavy damage, and in certain places total destruction. A squadron of the French Navy, rushing help to the stricken town, registered on the way two hitherto unknown depths of $15 \mathrm{~m}$. and $10 \mathrm{~m}$. where charts indicated $900 \mathrm{~m}$. and $90 \mathrm{~m}$., respectively. To check these soundings taken visually, two vessels of the Navy made, the next day, a systematic search. At the places in question, no echo at all could be obtained.

At the moment of the earthquake, the trawler Rolando, heading south-west, passed approximately the place where later the $10-\mathrm{m}$. depth was observed. The crew reported that they felt three shocks, as if their boat had hit a solid object. The sea became very choppy for several minutes and a glow appeared in the sea, shifting rapidly towards the town of Agadir. Shortly afterwards they saw the lights in the town going out.

In spite of near-by badly damaged buildings, the quay walls were found practically without serious
deformation, with the exception of two short oil wharfs. The slip for the fishing boats had not suffered at all. The tide gauge at the time of the earthquake registered the choppy sea in the harbour usual during that time of the year on account of wind 